\title{
Pemanfaatan marketplace shopee sebagai strategi untuk meningkatkan pemasaran kain songket
}

\author{
Anita Desiani ${ }^{1 \star}$, Irmeilyana ${ }^{2}$, Ajeng Islamia Putri ${ }^{3}$, Enyta Yuniar ${ }^{4}$, Nur \\ Avisa Calista ${ }^{5}$, Siddiq Makhalli ${ }^{6}$, Ali Amran ${ }^{7}$
}

\footnotetext{
${ }^{1}$ Universitas Sriwijaya, Palembang, Indonesia, email: anita_desiani@unsri.ac.id

22Universitas Sriwijaya, Palembang, Indonesia, email: irmeilyana@unsri.ac.id

${ }^{3}$ Universitas Sriwijaya, Palembang, Indonesia, email: 08011181722002@student.unsri.ac.id

4Universitas Sriwijaya, Palembang, Indonesia, email:08011181722006@student.unsri.ac.id

5Universitas Sriwijaya, Palembang, Indonesia, email:08011281722024@student.unsri.ac.id

${ }^{6}$ Universitas Sriwijaya, Palembang, Indonesia, email: 08011381823060@student.unsri.ac.id

7 Universitas Sriwijaya, Palembang, Indonesia, email: ali_amran@mipa.unsri.ac.id

*Koresponden penulis
}

\section{Info Artikel}

Diajukan: 10 Des 2020

Diterima: 28 Apr 2021

Diterbitkan: 25 Mei 2021

Keywords:

songket cloth; traditional; market place;

penyandingan; shopee

Kata Kunci:

kain songket; tradisional; marketplace; penyandingan; shopee

Lisensi:

cc-by-sa

\begin{abstract}
South Sumatera songket woven cloth is one of the cultural assets of South Sumatera Province which is usually used at weddings and other traditional ceremonies. One of the villages which is famous as a producer of songket cloth is a Penyandingan Village. The songket cloth industry in Penyandingan Village experienced a decline in turnover of up to $60 \%$ during the Covid-19 pandemic. This is supported by the lack of knowledge of society regarding marketing strategies and technology in marketing products. For this reason, Shopee market management training is needed for songket cloth craftsmen and the Penyandingan Village society through the Sriwijaya University Thematic Community Service team program so that the marketing of songket fabrics can reach a wide market and be able to compete with other products. The method used is the lecture method including data collection planning and implementation of activities. The research analysis uses descriptive analysis to provide a general description of the implementation of the Shopee marketplace training. After the training was carried out, Penyandingan Village society was able to understand the material and apply it directly using the Shopee application, and could be applied on a sustainable scale so that sales of songket cloth could increase.
\end{abstract}

\section{Abstrak}

Kain tenun songket Sumatera Selatan merupakan salah satu aset budaya dari Provinsi Sumatera Selatan yang biasanya digunakan pada acara pernikahan dan upacara adat lainnya. Desa Penyandingan merupakan salah satu desa sebagai penghasil kain tenun songket di Sumatera Selatan. Selama masa pandemi Covid-19, industri kain tenun songket di Desa Penyandingan mengalami penurunan pemesanan sehingga kehilangan omzet sampai $60 \%$ dari biasanya. Hal ini didukung dengan minimnya pengetahuan masyarakat penyandingan mengenai strategi pemasaran dan teknologi dalam memasarkan produk. Untuk itu diperlukan pelatihan pengelolaan marketplace Shopee bagi pengrajin kain songket dan masyarakat Desa Penyandingan melalui program tim pengabdian KKN Tematik Universitas Sriwijaya. Kegiatan ini bertujuan memberikan pemahaman dan pengetahuan pemanfaatan marketplace 


\begin{abstract}
Shopee untuk pemasaran kain songket agar pemasaran kain songket dapat mencakup pasar yang lebih luas dan mampu bersaing dengan produk lainnya. Metode yang digunakan adalah metode ceramah diantaranya pengumpulan data melalui wawancara, perencanaan dan pelaksanaan kegiatan. Analisis penelitian menggunakan analisis deskriptif untuk memberikan gambaran secara umum atas pelaksanaan pelatihan marketplace Shopee. Setelah dilaksanakannya pelatihan terlihat dari hasil pre-test dan post-test yang telah dilakukan bahwa masyarakat penyandingan mampu memahami materi dan mengaplikasikannya secara langsung menggunakan aplikasi Shopee, serta dapat diterapkan dalam skala berkelanjutan sehingga dapat meningkatkan penjualan kain tenun songket selama masa pandemi Covid-19.
\end{abstract}

\title{
PENDAHULUAN
}

Kain tenun songket Sumatera Selatan (Sumsel) merupakan salah satu aset budaya dari Provinsi Sumatera Selatan yang terkenal sejak zaman Kerajaan Sriwijaya pada abad ke-7 hingga abad ke-13. Kain ini biasanya digunakan pada acara-acara resmi seperti pernikahan, penyambutan tamu agung, upacara adat dan lain-lainya. Kain songket terbuat dari serat bahan alam (katun atau sutera) dengan motif yang terbuat dari benang emas sebagai ciri khas dari kain tersebut. Kain ini dibuat dengan cara ditenun menggunakan alat tenun tradisional, sehingga pembuatan kain ini membutuhkan waktu yang cukup lama sekitar 20 hari. Harga dan kualitas kain songket tergantung pada jenis benang yang digunakan dan motif kain.

Industri kerajinan kain songket ini banyak tersebar di daerah Sumatera Selatan (Waluyati et al., 2016). Salah satu desa di sumsel yang terkenal sebagai penghasil kain songket khas Sumatera Selatan adalah Desa Penyandingan. Desa ini berada diwilayah Kecamatan Indralaya, Kabupaten Ogan Ilir, dengan jumlah penduduk sebanyak 646 orang (BPS Kabupaten Ogan Ilir, 2020). Mayoritas penduduk Desa Penyandingan berprofesi sebagai petani, dimana sekitar $20 \%$ adalah petani sayuran dan sisanya merupakan petani tumbuhan musiman. Selain bertani, masyarakat Desa Penyandingan juga berprofesi sebagai pengrajin songket, dimana disetiap rumah masyarakat setidaknya terdapat satu pengrajin songket. Pengrajin songket di Desa Penyandingan terdiri dari $90 \%$ ibu-ibu dan remaja putri sebagai salah satu alternatif untuk membantu perekonomian keluarga yang belum tercukupi dari hasil bertani.

Pada masa pandemik Covid-19 yang tengah menimpa seluruh negara didunia saat ini termasuk Indonesia, telah memberikan dampak negatif pada semua sektor kehidupan masyarakat terutama ekosistem ekonomi yang selama ini menjadi tumpuan masyarakat. Beberapa usaha tengah mengalami berbagai permasalahan seperti penurunan penjualan, permodalan, distribusi terhambat, dan kesulitan bahan baku. Hal ini pun dialami oleh para pengrajin kain songket di Desa Penyandingan, dimana terjadinya penurunan pemesanan dan produksi kain sehingga kehilangan omzet sampai $60 \%$ dari biasanya. Adapun faktor pendukung lainnya seperti minimnya pengetahuan masyarakat Desa Penyandingan mengenai strategi pemasaran dan pengetahuan teknologi untuk memasarkan suatu produk. Pemasaran kain 
songket di Desa Penyandingan masih dalam skala terbatas, dimana para pengrajin memasarkan produknya dengan cara dijual langsung ke pasar atau ke penadah sehingga jangkauan pemasaran kain songket hasil produksi Desa Penyandingan ini belum mencangkup pasar yang luas.

Strategi pemasaran merupakan salah satu faktor yang sangat penting dalam mepromosikan suatu produk untuk menjangkau lebih banyak konsumen. Strategi pemasaran yang cocok selama masa pandemik Covid-19 adalah pemasaran produk secara online (Desiani et al., 2020; Fadly \& Sutama, 2020). Pemanfaatan internet menjadi salah satu alternatif untuk melakukan pemasaran berbasis online, seperti marketplace (Suherman \& Hasanah, 2020). Marketplace merupakan sebuah platform yang memfasilitasi transaksi bisnis online seperti jual beli barang, jasa atau informasi secara online antara penjual dan pembeli dan penjual, dan lainnya (Yustiani \& Yunanto, 2017). Penggunaan marketplace sebagai sarana pemasaran online memiliki beberapa keuntungan bagi penjual diantaranya fleksibilitas waktu, tidak terdapat biaya operasional, tidak memerlukan promosi karena platform marketplace telah terdapat stategi promosi tersendiri, tidak membutuhkan biaya sewa, pengguna hanya perlu mendaftarkan toko onlinenya untuk berjualan, meningkatkan pelayanan dan promo, dan sebagainya (Pratomo et al., 2019). Berdasarkan data BPS, peningkatan produk yang terjual di marketplace dalam kurun waktu April 2020 hingga Juni 2020 (masa pandemi) meningkat sekitar 20\% dari bulan-bulan sebelumnya (Hidayat, 2020). Salah satu marketplace yang meningkat sangat pesat di Indonesia adalah Shopee. Marketplace Shopee selalu mengadakan promosi tahunan sehingga pada tahun 2018 dicatat telah melampaui semua jenis rekor penjualan pada tahun lalu (Nurzanah et al., 2018).

Beberapa penelitian telah memanfaatan marketplace Shopee sebagai sarana pemasaran produk Usaha Rumah Tangga atau UMKM di desa seperti yang dilakukan oleh Hadi \& Khairi (2020) memberikan pelatihan marketplace Shoppe kepada ibu-ibu PKK di Desa Gadingharjo sebagai strategi pemasaran produk di era digital dan industri 4.0, Sulistiyawati \& Widayani (2020) memanfaatkan marketplace Shopee sebagai media promosi penjualan UMKM di Kota Blitar, Prayogo \& Nurdian (2020) memanfaatkan marketplae Shopee untuk pemasaran Bawang Goreng di Desa Sumberdadap Tulungagung, dan Sugiarti et al. (2020) memberikan pelatihan marketplace Shoppe untuk meningkatkan daya saing pada UMKM sambal DEDE SATOE di Jawa Timur. Berdasarkan permasalahan yang telah dijabarkan sebelumnya, untuk menjaga keberlanjutan dan peningkatan pemasaran kain songket di Desa Penyandinga, maka tim pengabdian KKN Tematik Universitas Sriwijaya akan melaksanakan kegiatan pelatihan dalam praktik pemasaran kain songket dengan memanfaatkan marketplace Shopee kepada pengrajin kain songket, karang taruna, dan UMKM yang ada di Desa Penyandingan. Dari kegiatan ini diharapkan masyarakat Desa Penyandingan mampu mempromosikan dan meningkatkan penjualan kain songket melalui strategi pemasaran yang tepat agar pemasaran kain songket dapat mencakup pasar yang lebih luas dan mampu bersaing dengan produk lainnya. 


\section{METODE PELAKSANAAN}

Pelaksanaan kegiatan pelatihan dilaksanakan dari bulan Oktober 2020 sampai dengan bulan Desember 2020 di Desa Penyandingan Kecamatan Indralaya Kabupaten Ogan Ilir. Subjek pada kegiatan ini adalah Karang Taruna dan Kelompok-kelompok Usaha Mikro, Kecil dan Menengah (UMKM) yang ada di Desa Penyandingan.

Prosedur pada pelaksanaan kegiatan ini memiliki beberapa tahap, seperti pengumpulan data (accumulation) dan pelaksanaan atau tindakan (action). Pengumpulan data dalam pelaksanaan kegiatan ini terdiri dari 2 tahap yaitu wawancara dan pembagian pre-test serta post-test. Pada tahap wawancara ini dilakukan secara langsung dengan Kepala Desa Penyandingan Indralaya dan perangkat desa guna mengetahui kondisi pengetahuan masyarakat Desa Penyandingan Indralaya terhadap perkembangan dan pemanfaatan pada aplikasi belanja online lebih lanjut. Sedangkan pada tahap pembagian kuesioner dilakukan dengan cara membagikan kuesioner ke peserta workshop guna mengetahui sejauh mana pengalaman dan keahlian dalam menggunakan aplikasi belanja online dan agar dapat menyesuaikan materi yang akan disampaikan oleh pemateri.

Pada tahap pelaksanaan atau tindakan dilakukan presentasi yang telah dirancang untuk meningkatkan pengetahuan peserta dari hal yang mendasar atau pengertian belanja online sampai manfaat dan kegunaanya untuk mendapatkan hasil yang maksimal. Pada kegiatan awal, proses kegiatan dengan mengucapkan salam, lalu dilanjutkan dengan pembukaan serta kepada pemateri yang bertugas. Lalu pemateri memulai menjelaskan apa yang ingin disampaikannya dengan materi yang telah dirancang dan dibuat. Dikarenakan peserta yang sudah mengerti sebagian tentang aplikasi Selanjutnya pematerii memberi tahu manfaat, kegunaan, dan keuntungan menggunakan aplikasi belanja online dari toko offline yang lebih rinci kepada peserta, dan presentator menyampaikannya sesuai dengan materi yang telah dirancang. Selanjutnya metode praktik sangat penting dalam membantu peserta dalam memahamii materi yang disampaikan, dengan metode praktik inilah peserta langsung mencoba mengaplikasikan ilmu dan keterampilannya sehingga membuat peserta lebih mudah ingat dan paham

Gambaran tahap-tahap prosedur pelaksanaan kegiatan dapat dilihat dalam bentuk diagram alir pada gambar 1 sebagai berikut. 


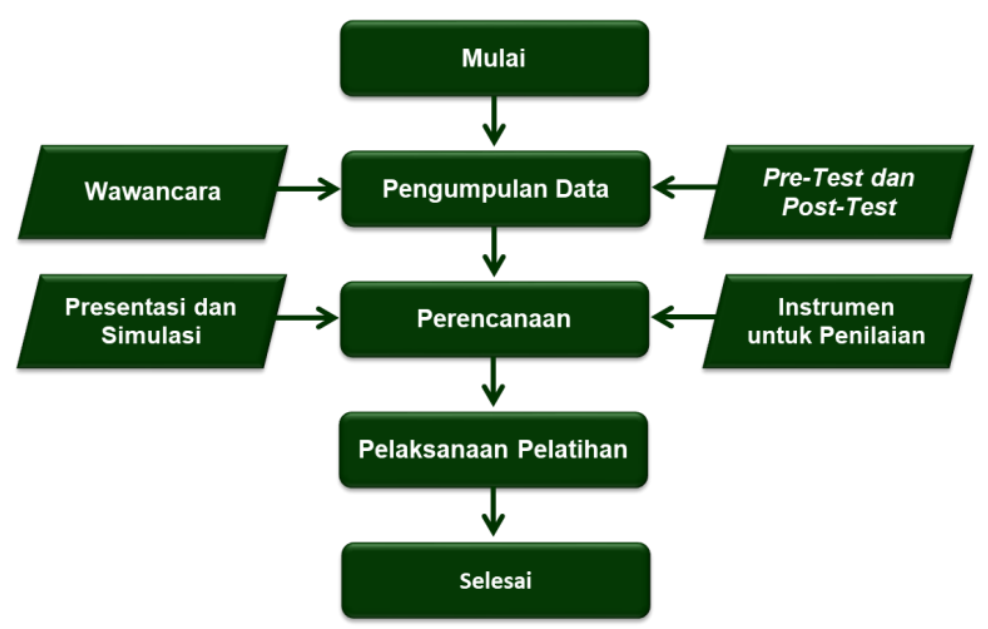

Gambar 1. Diagram Alir Pelaksanaan Kegiatan

Dalam kegiatan ini, analisis data yang digunakan yaitu analisis deskriptif yang memberikan gambaran secara umum mengenai kondisi dan kebiasaan masyarakat Desa penyandingan. Penyajian data disajikan pada tabel 1.

Tabel 1. Tabel identifikasi masalah, solusi, dan hasil luaran

\begin{tabular}{|c|c|c|c|}
\hline No & Permasalahan & Solusi & Luaran \\
\hline 1. & $\begin{array}{l}\text { Kurangnya pengetahuan } \\
\text { dan pemahaman mitra } \\
\text { mengenai teknologi yang } \\
\text { dapat digunakan untuk } \\
\text { memperluas pasar } \\
\text { penjualan kain songket. }\end{array}$ & $\begin{array}{l}\text { Sosialisasi mengenai } \\
\text { marketplace serta } \\
\text { manfaat yang } \\
\text { didapatkan dari } \\
\text { penggunaan } \\
\text { marketplace. }\end{array}$ & $\begin{array}{l}\text { Peningkatan pengetahuan } \\
\text { dan pemahaman mitra } \\
\text { mengenai teknologi yang } \\
\text { dapat digunakan untuk } \\
\text { memperluas pasar penjualan } \\
\text { kain songket. }\end{array}$ \\
\hline 2. & $\begin{array}{l}\text { Kurangnya pemahaman } \\
\text { mitra dalam } \\
\text { mengoperasikan aplikasi } \\
\text { marketplace sebagai sarana } \\
\text { pemasaran kain songket. }\end{array}$ & $\begin{array}{l}\text { Pelatihan mengenai } \\
\text { cara mengoperasikan } \\
\text { aplikasi toko online. }\end{array}$ & $\begin{array}{l}\text { Peningkatan pemahaman } \\
\text { mitra dalam mengoperasikan } \\
\text { aplikasi toko online sebagai } \\
\text { sarana pemasaran kain } \\
\text { songket. }\end{array}$ \\
\hline 3. & $\begin{array}{l}\text { Menurunnya pemasukan } \\
\text { pengrajin songket } \\
\text { dikarenakan dampak dari } \\
\text { pandemi Covid-19. }\end{array}$ & $\begin{array}{l}\text { Pelatihan pembuatan } \\
\text { akun toko online } \\
\text { sebagai media } \\
\text { pemasarann kain } \\
\text { songket. }\end{array}$ & $\begin{array}{l}\text { Akun toko online sebagai } \\
\text { media pemasaran kain } \\
\text { songket. }\end{array}$ \\
\hline
\end{tabular}

\section{HASIL DAN PEMBAHASAN}

Pengrajin kain songket di Desa Penyandingan biasanya dalam memasarkan produknya dengan cara dijual langsung ke pasar sehingga jangkauan pemasaran kain songket khas Palembang belum mencangkup jangkauan pasar yang luas. Maka dari itu dilaksanakannya kegiatan pelatihan mengenai pemanfaatan marketplace sebagai alternatif untuk meningkatkan pemasaran kain songket. Pada kegiatan pelatihan ini dilakukan pendampingan dan pelatihan dengan memberikan pengetahuan, pemahaman serta pemanfaatan aplikasi marketplace yang digunakan sebagai sarana 
untuk meningkatkan pemasaran kain songket. Tahap awal pada kegiatan program kami yang dilaksanakan di Desa Penyandingan, Kecamatan Indralaya adalah melakukan peninjauan mengenai cara penjualan yang dilakukan oleh tiap pengrajin songket di Desa Penyandingan dan mengukur seberapa besar pengrajin memahami tentang media penjualan salah satunya adalah marketplace. Kegiatan ini dilakukan dengan melakukan wawancara terhadap pengrajin songket di Desa Penyandingan yang berguna untuk mengetahui seberapa lama pembuatan songket dan cara penjualannya. Wawancara bersama salah satu pengrajin songket dapat dilihat pada gambar 2.

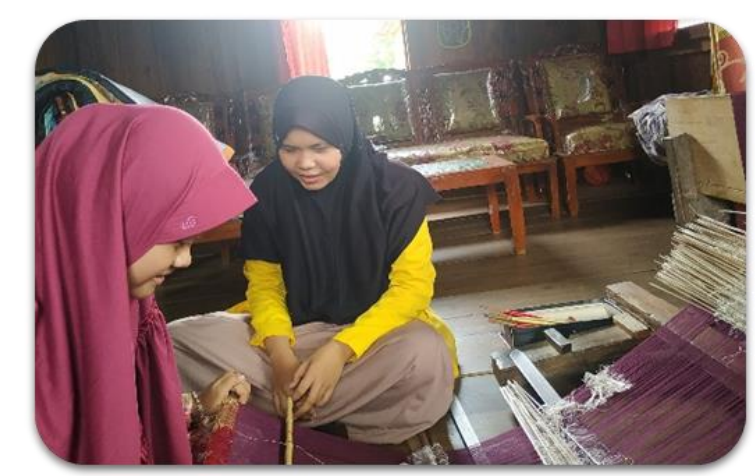

Gambar 2. Wawancara dengan Salah Satu Pengrajin Songket Desa Penyandingan

Setelah didapatkan hasil dari wawancara. Maka, kegiatan selanjutnya adalah kegiatan perencanaan. Kegiatan perencanaan terdiri tiga tahapan yaitu menyusun materi sebagai bahan ajar serta mempersiapkan akun penjualan yang akan digunakan sebagai media pembelajaran dan instrument penilaian dimana instrument penilaian ini terdiri dari pre-test dan post-test. Kami telah menyiapkan pertanyaan-pertanyaan yang nantinya akan kami tanyakan pada saat sebelum dan sesudah pelatihan yang akan kami lakukan. pada soal pretest kami menyiapkan pertanyaan-pertanyaan yang berhubungan dengan materi marketplace yang akan kami sampaikan. Selain itu, kami juga menyiapkan pertanyaan-pertanyaan yang nantinya akan kami tanyakan setelah pelatihan selesai atau yang disebut dengan post-test, isi dari pertanyaan tersebut adalah materi tentang salah satu aplikasi yang telah diajarkan pada saat pelatihan. Setelah dilakukan berbagai persiapan, kegiatan selanjutnya adalah kegiatan pelaksanaan, dimana pada kegiatan inilah semua yang telah disiapkan kami laksanakan. Kegiatan ini diawali dengan melakukan pembagian pre-test yang akan diisi oleh seluruh peserta pelatihan. Pengisian soal pre-test oleh peserta pelatihan marketplace dapat dilihat pada gambar 3 . 


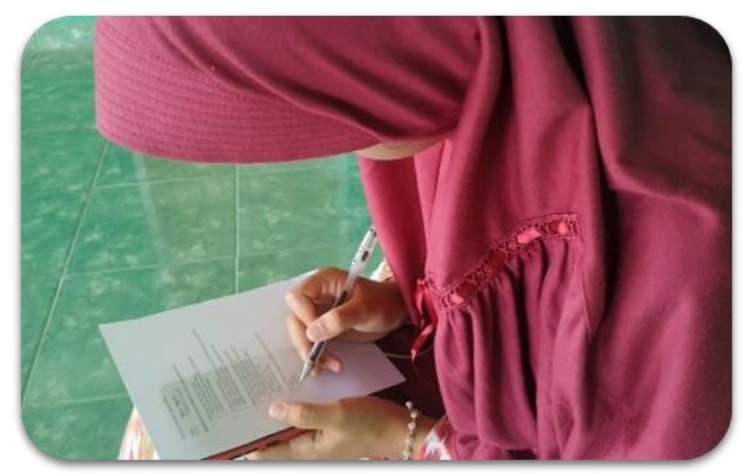

Gambar 3. Pengisian Pre-test Bagi peserta Pelatihan

Setelah melakukan pre-test tersebut, tim KKN Tematik langsung memaparkan materi yang telah disiapkan sebelumnya, pemaparan materi dilakukan dengan menampilkan PPT yang berisi tentang materi marketplace yang dapat dilihat pada gambar 4 .

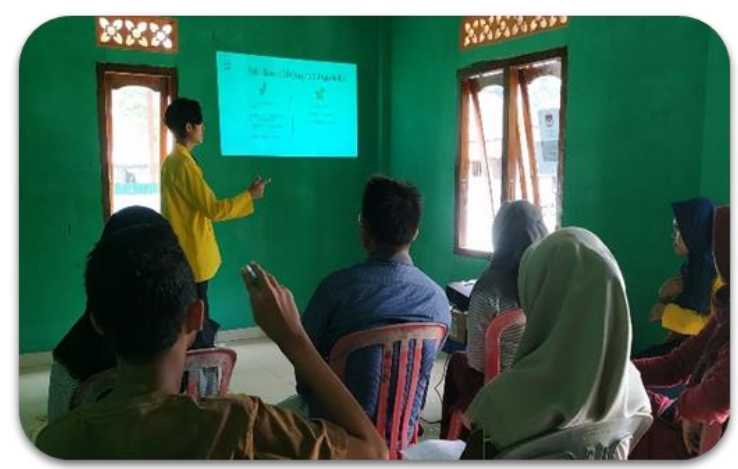

Gambar 4. Penjelasan Materi Pelatihan Marketplace

Selanjutnya, kami menjelaskan mengenai cara pembuatan salah satu aplikasi marketplace yaitu pembuatan akun penjualan di Shopee dengan tujuan agar peserta pelatihan dapat melakukan penjualan songket menggunakan akun tersebut. Pada pembuatan akun Shopee kami mengajak peserta untuk ikut serta dalam membuat akun dan mencoba berbagai fitur-fitur yang mendukung untuk meninggkatkan penjualan. Berikut ini adalah contoh akun dari salah satu peserta yang mengikuti pelatihan dapat dilihat pada gambar 5. 


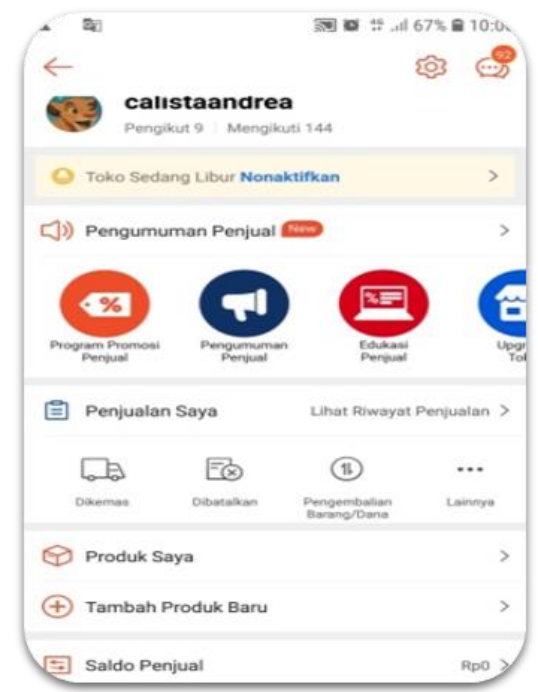

Gambar 5. Akun Shoope dari Salah Satu Peserta Pelatihan

Setelah selesai melakukan pemaparan materi dan pembuatan akun Shopee, kami memberikan pertanyaan post-test. Post-test ini dilakukan untuk mengetahui apakah peserta memperhatikan apa yang telah kami jelaskan dan materi yang telah dipaparkan tersebut berhasil tersampaikan dengan baik. Dalam menentukan persentase pencapaian kriteria dapat dikelompokkan menjadi 4 skala penilaian yaitu jika nilai yang diperoleh $\leq 55$ maka kriteria penilaian "kurang baik", jika nilai yang diperoleh 56-70 maka kriteria penilaian "cukup", jika nilai yang diperoleh 71-85 maka kriteria penilaian "baik", dan jika nilai yang diperoleh 86-100 maka kriteria penilaian "sangat baik". Persentase pencapaian kriteria pengetahuan marketplace dari hasil pre-test dapat diketahui melalui pemaparan data yang dapat dilihat pada tabel 2.

Tabel 2. Rekapitulasi Pencapaian Tingkat Pengetahuan Marketplace dari Hasil Pre-Test

\begin{tabular}{clcc}
\hline No & Kriteria & Jumlah peserta & Persentase \\
\hline 1 & Sangat Baik & - & - \\
2 & Baik & 1 & $10 \%$ \\
3 & Cukup & 5 & $50 \%$ \\
4 & Kurang Baik & 4 & $40 \%$ \\
& Total & 10 & $100 \%$ \\
\hline
\end{tabular}

Hasil yang diperoleh dari pemaparan Tabel 2 diatas menunjukkan bahwa tidak ada peserta pelatihan yang memperoleh kriteria sangat baik, untuk pencapaian kriteria baik pada hasil pre-test yang dilakukan sebelum pelatihan adalah $10 \%$ dengan jumlah peserta 1 orang. Selanjutnya untuk pencapaian kriteria cukup paling banyak diperoleh oleh peserta pelatihan dengan jumlah peserta 5 orang atau dengan presentase $50 \%$. Sedangkan untuk pencapaian kriteria kurang baik diperoleh sebanyak 4 orang peserta atau dengan presentase $40 \%$. Jika dilihat dari hasil pencapaian tersebut 
terlihat bahwa peserta masih rendah tingkat pengetahuannya mengenai marketplace.

Selanjutnya dilakukan pemaparan materi mengenai marketplace dan fitur-fitur Shopee. Kemudian, peserta melakukan simulasi membuat akun penjualan di aplikasi Shopee dan simulasi mengenai fitur-fitur yang terdapat di Shopee. Setelah menyelesaikan pemaparan materi dan pembuatan akun. Selanjutnya, kami membagikan soal post-test kepada peserta pelatihan dengan tujuan untuk mengetahui seberapa baik peserta memahami materii yang telah diberikan. Berikut adalah hasil rekapitulasi dari post-test yang telah dibagikan.

Tabel 3. Rekp Tingkat Pengetahuan Marketplace dari Hasil Post-test yang Telah Dibagikan

\begin{tabular}{clcc} 
No & Kriteria & Jumlah peserta & Persentase \\
\hline 1 & Sangat Baik & 5 & $50 \%$ \\
2 & Baik & 4 & $40 \%$ \\
3 & Cukup & 1 & $10 \%$ \\
4 & Kurang Baik & - & - \\
& Total & 10 & $100 \%$ \\
\hline
\end{tabular}

Hasil yang diperoleh dari pemaparan tabel 3 diatas dapat menunjukkan bahwa pencapaian kriteria sangat baik memperoleh hasil sebanyak $50 \%$ dengan jumlah peserta sebanyak 5 orang, untuk pencapaian kriteria baik pada hasil post-test yang dilakukan setelah pelatihan adalah $40 \%$ dengan jumlah peserta 4 orang. Selanjutnya untuk pencapaian kriteria cukup paling banyak dengan jumlah peserta 1 orang atau dengan presentase $10 \%$. Sedangkan, tidak ada peserta yang memperoleh hasil pencapaian kriteria kurang baik. Hasil tersebut menunjukkan bahwa materi yang telah kami paparkan dapat diterima dengan baik oleh peserta pelatihan. Dari perbandingan hasil pre-test dan post-test didapatkan perbandingan tingkat pengetahuan marketplace yang dapat dilihat pada gambar 6 .

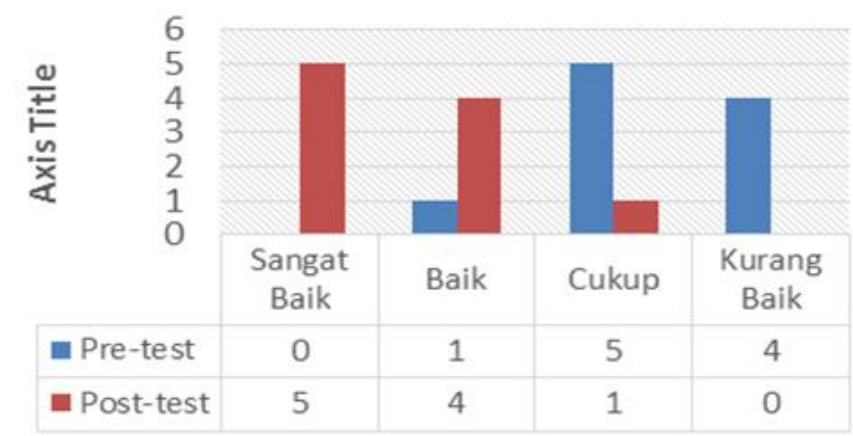

Gambar 6. Perbandingan hasil pre-test \&hasil post-test

Setelah dilaksanakannya pelatihan ini dan terlihat dari Gambar 6 perbandingan hasil pre-test dan post-test yang telah dilakukan bahwa masyarakat Desa Penyandingan telah mampu memahami materi dan 
mengaplikasikannya secara langsung menggunakan salah satu aplikasi marketplace yaitu Shopee, serta dapat diterapkan dalam skala berkelanjutan sehingga dapat meningkatkan penjualan kain tenun songket selama masa pandemi Covid-19.

\section{KESIMPULAN}

Sehingga dapat disimpulkan bahwa sebelumnya peserta kurang memahami mengenai aplikasi marketplace yang berguna sebagai media penjualan dan pemasaran kain songket. Setelah, dilaksanakannya kegiatan pelatihan mengenai pemanfaatan marketplace peserta telah mampu memahami materi yang disampaikan dengan baik dan mengaplikasikannya secara langsung pada penjualan kain songket miliknya untuk memperoleh jangkauan pasar yang lebih luas, serta dapat diterapkan dalam skala berkelanjutan. Dalam memasarkan kain songket menggunakan aplikasi Shopee terdapat berbagai fitur-fitur menarik yang berguna untuk meningkatkan penjualan kain songket selama masa pandemi Covid-19.

\section{UCAPAN TERIMA KASIH}

Terima kasih kepada Rektor Universitas Sriwijaya Prof. Dr. Ir. H. Anis Saggaff, MSCE atas bantuan pendanaan kegiatan KKN Tematik UNSRI tahun 2020 berdasarkan surat keputusan Rektor Universitas Sriwijaya nomor 0006/UN9/SK.LP2M.PM2020.

\section{DAFTAR RUJUKAN}

BPS Kabupaten Ogan Ilir. (2020). Kecamatan Indralaya Dalam Angka 2020.

Desiani, A., Yahdin, S., Irmeilyana, I., \& Rodiah, D. (2020). Inovasi digitalisasi promosi potensi dan produk usaha masyarakat desa berbasis website di Desa Bangsal Kecamatan Pampangan. Riau Journal of Empowerment, 3(1), 49-59. https://doi.org/10.31258/raje.3.1.49-59

Fadly, H. D., \& Sutama. (2020). Membangun pemasaran online dan digital branding ditengah pandemi covid-19. Jurnal Ecoment Global: Kajian Bisnis Dan Management, 5(2), 213-222. https://doi.org/10.35908/jeg.v5i2.1042

Hadi, A. S., \& Khairi, A. (2020). Pemilihan Strategi Pemasaran Di Era Digital Pada Kelompok lbu Pkk Desa Gadingharjo. Dinamisia: Jurnal Pengabdian Kepada Masyarakat, 4(1), 127-132. https://doi.org/10.31849/dinamisia.v4i1.3246

Hidayat, K. (2020). BPS: Penjualan di marketplace meningkat pada masa pandemi corona. In Kontan.

Nurzanah, I., Sosianika, A., \& Kunci, K. (2018). Promosi Penjualan dan Minat Beli: Penerapan Modifikasi Technology Acceptance Model di EMarketplace Shopee Indonesia. 706-714.

Pratomo, A., Najwaini, E., Irawan, A., \& Risa, M. (2019). Optimasi ECommerce Dengan Penerapan Teknik Seo (Search Engine Optimization) Untuk Meningkatkan Penjualan Pada Ukm Nida Sasirangan. Jurnal IMPACT: Implementation and Action, 1(1), 35. 
https://doi.org/10.31961/impact.v1i1.615

Prayogo, F., \& Nurdian, Y. (2020). Resureksi Bawang Goreng Produk Unggulan Sumberdadap Tulungagung di Tengah Pandemi. Jurnal IImiah Pangabdhi, $6(2)$, 145-149. https://doi.org/10.21107/pangabdhi.v6i2.8278

Sugiarti, Y., Sari, Y., \& Hadiyat, M. A. (2020). E-Commerce untuk Meningkatkan Daya Saing Usaha Mikro Kecil dan Menengah (UMKM) Sambal di Jawa Timur. Kumawula: Jurnal Pengabdian Kepada Masyarakat, 3(2), 298. https://doi.org/10.24198/kumawula.v3i2.28181

Suherman, E., \& Hasanah, R. U. (2020). Analisis Pelatihan Marketplace bagi Pelaku Usaha Kue di Masa Pandemik Covid-19 di Desa Jatiragas. Jurnal Manajemen \& Bisnis Kreatif, 6(1), 98-110. https://doi.org/10.36805/manajemen.v6i1.1202

Sulistiyawati, E. S., \& Widayani, A. (2020). Marketplace Shopee Sebagai Media Promosi Penjualan Umkm di Kota Blitar. Jurnal Pemasaran Kompetitif, 4(1), 133-142. https://doi.org/10.32493/jpkpk.v4i1.7087

Waluyati, S. A., Kurnisar, \& Sulkipani. (2016). Analisis Upaya-Upaya Pengrajin Tenun Songket Dalam Mempertahankan Kelangsungan Usaha Di Desa Sudimampir Kecamatan Indralaya Kabupaten Ogan Ilir. Profit, 3(1), 67-72. https://doi.org/10.36706/jp.v3i1.5556

Yustiani, R., \& Yunanto, R. (2017). Peran Marketplace Sebagai Alternatif Bisnis Di Era Teknologi Informasi. Komputa: Jurnal IImiah Komputer Dan Informatika, $6(2)$, 43-48. https://doi.org/10.34010/komputa.v6i2.2476 